\title{
Pengaruh Diabetes, Hipertensi, Merokok dengan Kejadian Katarak di Balai Kesehatan Mata Makassar
}

\author{
Herlinda Mahdania Harun ${ }^{1}$, A. Zulkifli Abdullah'², Ummu Salmah ${ }^{3}$ \\ Bagian Epidemiologi, Fakultas Kesehatan Masyarakat, Universitas Hasanuddin ${ }^{1,2,3}$ \\ herlindamahdania.epid10@gmail.com
}

\begin{abstract}
Diajukan 13 Desember 2019 Diperbaiki 28 Januari 2020 Diterima 18 Februari 2020 ABSTRAK

Latar Belakang: Kebutaan dan gangguan penglihatan terbanyak diseluruh dunia adalah katarak dengan persentase $51 \%$ atau terjadi sekitar 20 juta jiwa. Angka kebutaan di Indonesia menempati urutan ketiga di dunia. Katarak merupakan penyebab utama kebutaan di Indonesia. Tujuan: Penelitian ini bertujuan untuk mengetahui risiko diabetes melitus, hipertensi, dan kebiasaan merokok, terhadap kejadian katarak pada pengunjung di Balai Kesehatan Mata Masyarakat Kota Makassar tahun 2017.

Metode: Penelitian ini dilakukan dengan menggunakan desain penelitian case control. Penarikan sampel dilakukan dengan sistematik random sampling. Jumlah sampel sebanyak 150

inklusi yang terdiri dari 75 kasus katarak dan 75 kontrol. Data dianalisis menggunakan uji Odds Ratio.

Hasil: Hasil penelitian menunjukkan bahwa faktor yang signifikan berisiko terhadap kejadian katarak, yaitu diabetes melitus (OR=4,750, 95\%CI: 2,3529,594), hipertensi (OR=4,9555, 95\%CI: 2,418-10,153), dan kebiasaan merokok (OR=3,696, 95\%CI: 1,826$7,482)$.

Kesimpulan: Faktor yang signifikan berisiko terhadap kejadian katarak yaitu diabetes, hipertensi, dan kebiasaan merokok. Disarankan perlunya untuk mengontrol gula darah, tekanan darah, dan berhenti merokok untuk mencegah serta deteksi dini penyakit katarak.
\end{abstract} responden umur $\geq 40$ tahun dan memenuhi kriteria Kata Kunci: diabetes; hipertensi; merokok; katarak

\section{ABSTRACT}

Background: Blindness and visual impairment is the most worldwide in cataracts by $51 \%$ or about 20 million people. Blindness in Indonesia ranks third in the world. Cataract is a major cause of blindness in Indonesia

Objective: This study aims to determine the risk of diabetes melitus, hypertension, and smoking habits, to the incidence of cataracts at visitors in eye health center of Makassar City Year 2017.

Methods: This research was conducted by using case control design study. Sampling was done by systematic random sampling. The sample size was 150 respondents aged $\geq 40$ years and fulfilled inclusion criteria consisting of 75 cases of cataracts and 75 controls. Data were analyzed using Odds Ratio test.

Result: The results showed that the factors that were significantly at risk for cataract incidence were diabetes melitus (OR=4,750, 95\%CI: 2,352-9,594), hypertension $(\mathrm{OR}=4,9555,95 \% \mathrm{CI}: 2,418-10,153)$, and smoking habit (OR=3,696, 95\%CI: 1,826-7,482).

Conclusion: Significant risk factors for cataracts are diabetes, hypertension, and smoking habits. Suggested the need to control blood sugar, blood pressure, and stop smoking to prevent and early detection of cataracts.

Keywords: diabetes; hypertension; smoking; cataracts 


\section{LATAR BELAKANG}

Katarak terjadi akibat kekeruhan pada lensa mata yang mengakibatkan tergantungnya cahaya masuk ke dalam bola mata, sehingga penglihatan menjadi kabur dan lama kelamaan dapat menyebabkan kebutaan (Ilyas, 2014). Menurut Global Data on Visual Impairment tahun 2010 penyebab gangguan penglihatan terbanyak diseluruh dunia adalah kelainan refraksi (43\%), katarak (33\%) dan glaukoma ( $2 \%)$, sedangkan penyebab kebutaan terbanyak di seluruh dunia adalah katarak sebesar 51\% atau terjadi sekitar 20 juta jiwa (WHO, 2012).

Angka kebutaan di Indonesia menempati urutan ketiga di dunia. Hingga saat ini sekitar 3,1 juta $(15 \%)$ penduduk Indonesia mengalami kebutaan. Katarak merupakan penyebab utama kebutaan di Indonesia sebesar 0,78\% (Badan Penelitian dan Pengembangan Kesehatan, 2008) dan prevalensi katarak di Sulawesi Selatan sebesar (2,5\%) (Badan Penelitian dan Pengembangan Kesehatan, 2013).

Katarak dapat ditemukan pada semua kelompok umur, umumnya ditemukan terjadi pada umur 40 tahun keatas (Ilyas, 2009; Pusdatin Kementerian Kesehatan RI, 2014; Ravindran et al., ). Banyak faktor risiko terkait dengan kejadian katarak, salah satunya disebabkan oleh Diabetes Melitus. Adanya peningkatan metabolisme glukosa dalam lensa, menyebabkan penimbunan sorbitol yang dianggap berhubungan dengan perubahan osmotik, dan akhirnya menyebabkan kekeruhan lensa (Pollreisz and SchmidtErfurth, 2010). Beberapa penelitian menyatakan bahwa risiko katarak dilaporkan tinggi pada penderita diabetes melitus.

Penyakit sistemik lain seperti hipertensi juga berperan terhadap kejadian katarak. Prevalensi katarak ditemukan lebih tinggi di mata pasien hipertensi dibandingkan dengan pasien non hipertensi (Yu et al., 2014; Varma et al., 2016). Merokok juga dikaitkan dengan kejadian katarak. Dimana merokok dapat meningkatkan stress oksidatif pada lensa mata yang disebabkan oleh radikal bebas yang dihasilkan oleh asap rokok (Weintraub et al., 2002).

Data dari Balai Kesehatan Mata Masyarakat Kota Makassar berdasarkan jumlah kasus katarak 5 tahun terakhir (20122016) selalu berada pada 10 penyakit terbesar mata dan posisi pertama dengan jumlah kasus terbanyak di tahun 2013-2016. Dimana pada tahun 2013 prevalensi pasien katarak sebanyak 8392 kasus (27\%), tahun 2014 sebanyak 10.470 kasus (51\%), tahun 2015 sebanyak 13.051 kasus (51\%) dan tahun 2016 sebanyak 14.591 kasus (52\%) yakni kasus lama sebanyak 7963 dan kasus baru sebanyak 6628 dan terbanyak berumur 40 tahun keatas (BKMM Makassar, 2016). Risiko terjadinya katarak yang dapat menyebabkan gangguan penglihatan sampai kebutaan dihubungkan dengan berbagai faktor risiko, sehingga peneliti ini bertujuan untuk mengetahui risiko diabetes melitus, hipertensi, dan kebiasaan merokok yang berpengaruh terhadap kejadian katarak pada pengunjung di Balai Kesehatan Mata Masyarakat Kota Makassar tahun 2017.

\section{METODE}

\section{Lokasi dan Rancangan penelitian}

Penelitian ini dilakukan di Balai Kesehatan Mata Masyarakat Kota Makassar selama 2 bulan dari 24 Maret hingga 24 Mei 2017. Jenis penelitian yang digunakan adalah observasional analitik dengan desain case control. Variabel dependen dalam penelitian ini adalah kejadian katarak, sedangkan variabel independen dalam hal ini diabetes melitus, hipertensi, dan kebiasaan merokok.

\section{Populasi dan sampel}

Populasi dalam penelitian ini adalah populasi kasus yaitu semua orang umur $\geq 40$ tahun yang berkunjung dan tercatat pada register BKMM Makassar dan menderita katarak dan populasi kontrol yaitu semua orang umur $\geq 40$ tahun yang berkunjung di BKMM Makassar dan tidak menderita katarak serta penyakit mata lainnya. Penarikan sampel 
dilakukan dengan sistematik random sampling. Jumlah sampel sebanyak 150 responden umur $\geq$ 40 tahun dan memenuhi kriteria inklusi yang terdiri dari 75 kasus katarak dan 75 kontrol. Adapun kriteria inklusi pada kelompok kasus, yaitu : a) laki-laki dan perempuan berumur $\geq 40$ tahun, b) terdaftar sebagai penderita katarak pada buku register/ rekam medik BKMM Makassar, c) bersedia menjadi responden penelitian. Dan kriteria inklusi pada kelompok kontrol yaitu a) laki-laki dan perempuan berumur $\geq 40$ tahun, $b$ ) bukan penderita katarak dan tidak menderita penyakit mata lainnya, c) bersedia menjadi responden penelitian.

\section{Besar sampel}

Perkiraan besar sampel pada penelitian ini dilakukan dengan menggunakan rumus sampel uji hipotesis Odss Ratio (OR), dengan rumus dari(Lemeshow, 1997), sebagai berikut:

Keterangan $: \mathrm{n}=$ Besar sampel minimum pada kelompok kasus dan kontrol $Z_{1-\alpha / 2}=$ Tingkat kemaknaan untuk $\alpha=5 \%(0,05)$, sehingga nilai

\begin{tabular}{|c|c|}
\hline $\mathrm{n}$ & $=\begin{array}{c}\text { Besar sampel minimum pada } \\
\text { kelompok kasus dan kontrol }\end{array}$ \\
\hline $\mathrm{Z}_{1-\alpha / 2}$ & $\begin{aligned}= & \text { Tingkat kemaknaan untuk } \alpha=5 \% \\
& (0,05), \text { sehingga nilai } \\
& Z_{1-\alpha / 2}=1,96\end{aligned}$ \\
\hline $\mathrm{Z}_{1-\beta}$ & $\begin{aligned}= & \text { Tingkat kekuatan dari test } \beta=80 \% \\
& (0,8) \text { sehingga ditetapkan nilai } Z_{1}- \\
& \beta=0,84\end{aligned}$ \\
\hline OR & $\begin{array}{l}=\text { Odds Ratio sebesar 2,9 (Pujiyanto, } \\
\text { 2004). }\end{array}$ \\
\hline P1 & $\begin{array}{l}=\text { Perkiraan proporsi terpapar pada } \\
\text { kelompok kasus }\end{array}$ \\
\hline P2 & $\begin{array}{l}=\text { Perkiraan proporsi terpapar pada } \\
\text { kelompok kontrol sebesar } 29 \% \\
\text { atau } 0,29 \text { (Pujivanto, 2004). }\end{array}$ \\
\hline
\end{tabular}

Untuk menetapkan nilai P1, maka digunakan persamaan sebagai berikut:

$$
\begin{aligned}
& \mathrm{P} 1=\frac{(\mathrm{OR}) \mathrm{P} 2}{(\mathrm{OR}) \mathrm{P} 2+(1-\mathrm{P} 2)} \\
& \mathrm{P} 1=0,54
\end{aligned}
$$

Maka dapat dihitung besar sampel sebagai berikut:

$$
\begin{aligned}
& n=\frac{\left\{\mathrm{Z}_{1}-\alpha / 2 \sqrt{[2 \mathrm{P} 2(1-\mathrm{P} 2)]}+\mathrm{Z}_{1}-\beta \sqrt{[\mathrm{P} 1(1-\mathrm{P} 1)+\mathrm{P} 2(1-\mathrm{P} 2)]\}^{2}}\right.}{(\mathrm{P} 1-\mathrm{P} 2)^{2}} \\
& n=\frac{\left\{1,96 \sqrt{[2 \times 0,29 \times 0,71]}+0,84 \sqrt{[0,54 \times 0.46+0,29 \times 0,71\}^{2}}\right.}{(0,54-0,29)} \\
& n=60
\end{aligned}
$$

Besar sampel dalam penelitian ini adalah sampel dengan perbandingan antara kasus dan kontrol $1: 1$, sehingga besar sampel minimal untuk kasus ditambah kontrol adalah 120 orang. Guna menghindari kekurangan data maka jumlah sampel masing-masing ditambah $15 \%$ sehingga jumlah sampel dalam penelitian ini berjumlah 150 orang terbagi atas 75 kasus dan 75 kontrol.

\section{Metode pengumpulan data}

Pengumpulan data diperoleh dengan dua cara, yakni data primer meliputi wawancara langsung kepada responden dengan menggunakan kuesioner dan data sekunder yang didapatkan dari kartu rekam medik pasien.

\section{Analisis data}

Analisis data menggunakan uji statistik Odds Ratio (OR) melalui tabulasi silang. Data disajikan dalam bentuk tabel dan narasi.

\section{HASIL DAN PEMBAHASAN}

\section{Karakteristik sampel}

Distribusi responden berdasarkan umur, jenis kelamin, tingkat pendidikan, dan jenis pekerjaan. Berdasarkan kelompok umur didapatkan sebagian besar kasus katarak pada kelompok umur 56-65 tahun yaitu sebesar $34,7 \%$ (26 orang) sedangkan pada kontrol sebagian besar pada kelompok umur 40-45 tahun yaitu sebesar 36,0\% (27 orang). Berdasarkan jenis kelamin pada kelompok kasus paling banyak berjenis kelamin laki-laki yaitu sebesar 57,3\% (43 orang) sedangkan pada kontrol paling banyak berjenis kelamin perempuan yaitu 68,0\% (51 orang). Tingkat pendidikan pada kasus katarak terbanyak adalah tidak tamat SD sebesar 28,0,\% (21 orang) dan pada kontrol dengan tingkat pendidikan terbanyak adalah tamat SMA 42,7\% (32 orang). Jenis pekerjaan pada kasus katarak terbanyak yakni sebagai petani/ nelayan/ buruh 
bangunan/ pekerja bengkel sebesar 34,7\% (26 terbanyak adalah ibu rumah tangga 56,0\% (42 orang) dan pada kontrol dengan jenis pekerjaan orang)(Tabel1).

Tabel 1. Disribusi Karakteristik Responden Berdasarkan Kelompok Umur, Jenis Kelamin, Tingkat Pendidikan, dan Jenis Pekerjaan pada Kelompok Kasus dan Kontrol di Balai Kesehatan Mata Makassar Tahun 2017

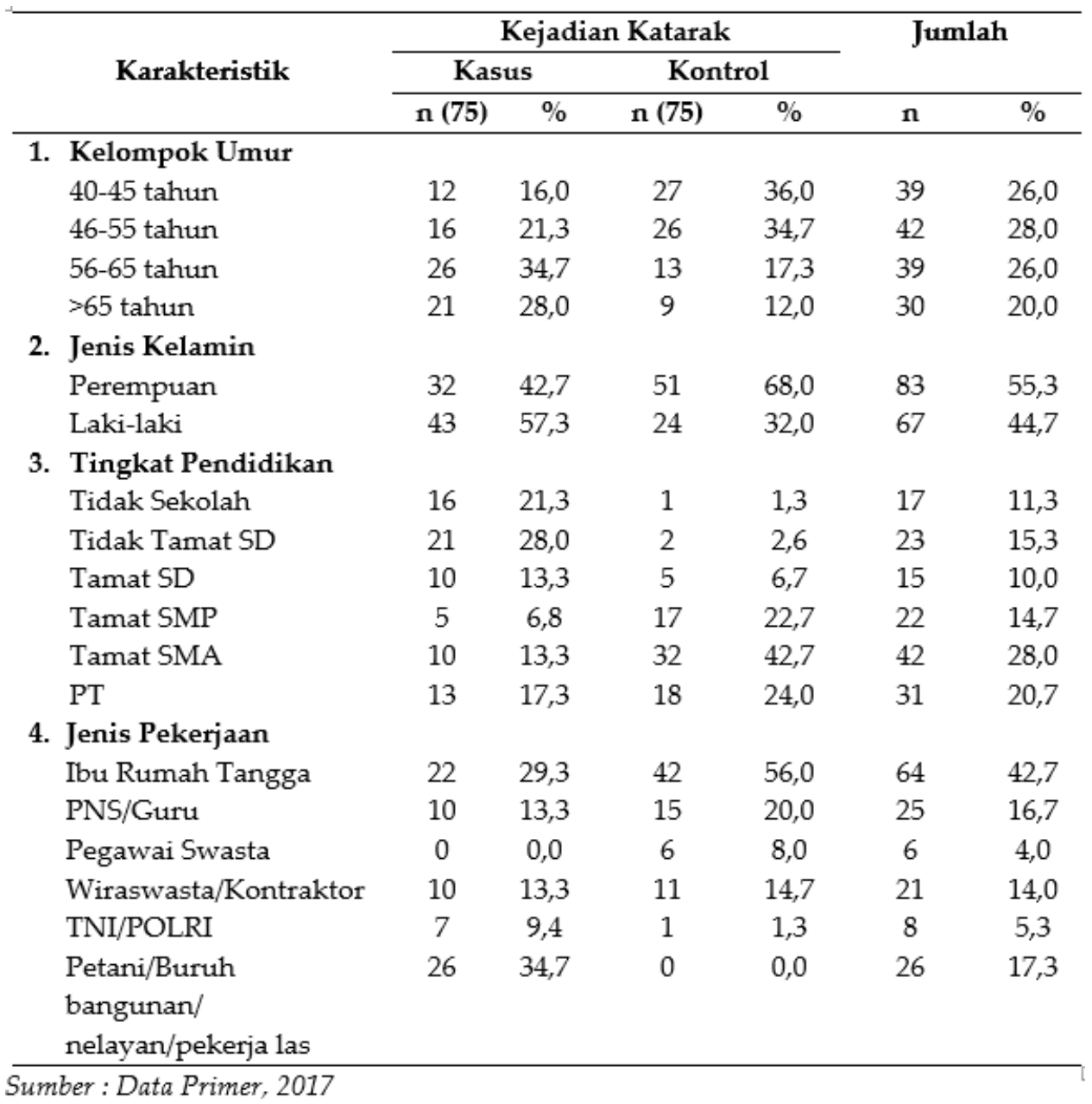

Distribusi responden berdasarkan variabel diabetes melitus, hipertensi, dan kebiasaan merokok. Berdasarkan variabel diabetes melitus dalam penelitian ini diperoleh pada kelompok kasus lebih banyak responden yang menderita diabetes melitus sebanyak 45 $(60,0 \%)$ dan pada kontrol sebanyak 57 (76,0\%) responden tidak menderita diabetes melitus. Responden yang menderita diabetes melitus pada kasus paling banyak dengan lama menderita diabetes melitus yakni $\geq 5$ tahun sebanyak $28(62,2 \%)$ dan pada kontrol lebih banyak dengan lama menderita diabetes melitus $<5$ tahun sebanyak $13(72,2 \%)$.

Variabel hipertensi dalam penelitian ini didapatkan distribusi responden katarak sebagian besar menderita hipertensi sebanyak
$43(57,3 \%)$ dan pada kontrol paling banyak tidak menderita hipertensi sebanyak 59 (78,7\%). Responden yang menderita hipertensi paling banyak dengan lama menderita hipertensi $\geq 5$ tahun baik pada kelompok kasus sebanyak $30(69,8 \%)$ demikian juga pada kelompok kontrol sebanyak 9 (56,2\%). Terdapat 39 responden $(52,0 \%)$ pada kelompok kasus katarak yang memiliki kebiasaan merokok dan 58 responden kontrol $(77,3 \%)$ yang tidak memiliki kebiasaan merokok. Untuk responden yang merokok pada kasus paling banyak jumlah batang rokok yang dikonsumsi 11-15 batang/ hari yaitu sebanyak 19 (48,7\%) dan pada kontrol yaitu 5-10 batang/hari sebanyak $13(76,5 \%)$ (Tabel 2). 
Tabel 2. Disribusi Responden Berdasarkan Variabel Diabetes, Hipertensi, dan Kebiasaan Merokok pada Kelompok Kasus dan Kontrol di Balai Kesehatan Mata Makassar Tahun 2017.

\begin{tabular}{|c|c|c|c|c|c|c|}
\hline \multirow{3}{*}{ Variabel } & \multicolumn{4}{|c|}{ Kejadian Katarak } & \multicolumn{2}{|c|}{ Jumlah } \\
\hline & \multicolumn{2}{|c|}{ Kasus } & \multicolumn{2}{|c|}{ Kontrol } & \multirow[b]{2}{*}{$\mathbf{n}$} & \multirow[b]{2}{*}{$\%$} \\
\hline & $\mathbf{n}$ & $\%$ & $\mathbf{n}$ & $\%$ & & \\
\hline \multicolumn{7}{|l|}{ 1. Diabetes Melitus } \\
\hline Menderita & 45 & 60,0 & 18 & 24,0 & 63 & 42,0 \\
\hline Tidak Menderita & 30 & 40,0 & 57 & 76,0 & 87 & 58,0 \\
\hline \multicolumn{7}{|c|}{ Lama Menderita DM } \\
\hline$\geq 5$ tahun & 28 & 62,2 & 5 & 27,8 & 33 & 52,4 \\
\hline$<5$ tahun & 17 & 37,8 & 13 & 72,2 & 30 & 47,6 \\
\hline \multicolumn{7}{|l|}{ 2. Hipertensi } \\
\hline Menderita & 43 & 57,3 & 16 & 21,3 & 59 & 39,3 \\
\hline Tidak menderita & 32 & 42,7 & 59 & 78,7 & 91 & 60,7 \\
\hline \multicolumn{7}{|c|}{ Lama Menderita Hipertensi } \\
\hline$\geq 5$ tahun & 30 & 69,8 & 9 & 56,2 & 39 & 66,1 \\
\hline$<5$ tahun & 13 & 30,2 & 7 & 43,8 & 20 & 33,9 \\
\hline \multicolumn{7}{|l|}{ 3. Kebiasaan Merokok } \\
\hline Merokok & 39 & 52,0 & 17 & 22,7 & 56 & 37,3 \\
\hline Tidak merokok & 36 & 48,0 & 58 & 77,3 & 94 & 62,7 \\
\hline \multicolumn{7}{|c|}{ Jumlah batang rokok yang } \\
\hline \multicolumn{7}{|l|}{ dikonsumsi } \\
\hline $5-10$ batang/hari & 6 & 15,4 & 13 & 76,5 & 19 & 33,9 \\
\hline $11-15$ batang/hari & 19 & 48,7 & 3 & 17,6 & 22 & 39,3 \\
\hline $16-20$ batang/hari & 14 & 35,9 & 1 & 5,9 & 15 & 26,8 \\
\hline
\end{tabular}

\section{Analisis Bivariat}

Hasil analisis bivariat untuk variabel Diabetes Melitus, hipertensi, dan kebiasaan merokok. Diketahui bahwa variable diabetes melitus dalam penelitian ini dari hasil uji statistik dengan nilai OR =4,750 (CI95\% : 2,352$9,594)$. Hal ini berarti responden yang menderita diabetes melitus mempunyai risiko menderita katarak sebesar 4,750 kali lebih besar dibandingkan dengan responden yang tidak menderita diabetes melitus.

Variabel hipertensi dalam penelitian ini menunjukkan hasil uji statistik dengan nilai OR
$=4,955(\mathrm{CI} 95 \%$ : 2,418-10,153). Hal ini berarti responden yang menderita hipertensi mempunyai risiko menderita katarak sebesar 4,955 kali lebih besar dibandingkan dengan responden yang tidak menderita hipertensi. Variabel kebiasaan merokok dari hasil uji statistik dengan nilai OR =3,696 (CI 95\% : 1,8267,482). Hal ini berarti bahwa responden yang memiliki kebiasaan merokok mempunyai risiko menderita katarak sebesar 3,696 kali lebih besar dibandingkan dengan responden yang tidak merokok (Tabel3).

Tabel 3. Analisis Bivariat Variabel Bebas Terhadap Kejadian Katarak

Pada Pengunjung di Balai Kesehatan Mata Makassar Tahun 2017.

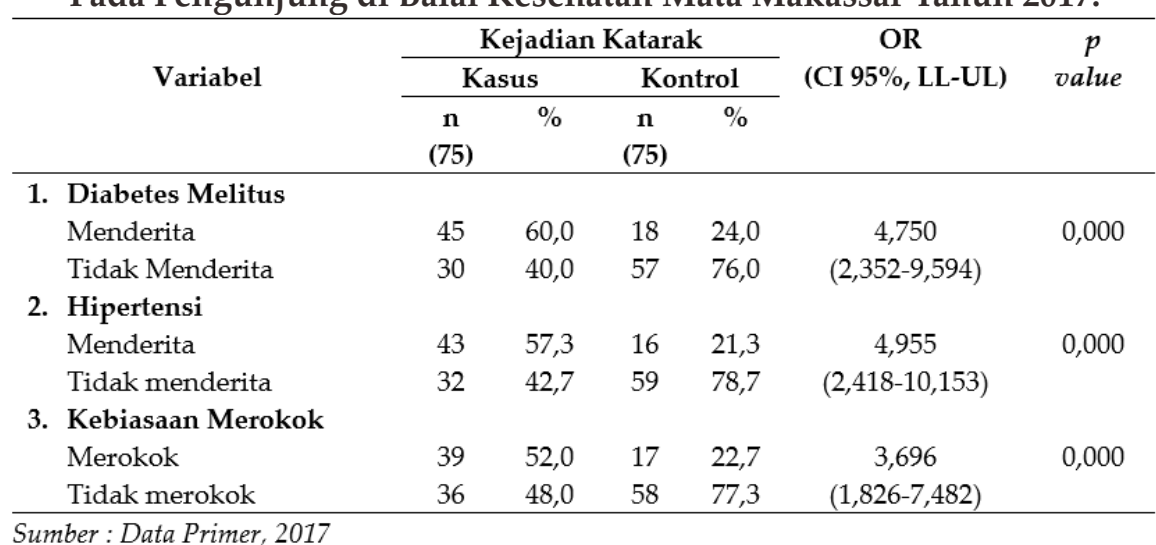


Penelitian ini diperoleh hasil bahwa penyakit diabetes melitus dapat mengakibatkan komplikasi gangguan penglihatan bahkan kebutaan seperti katarak. Pada penelitian ini diperoleh hasil bahwa responden yang menderita diabetes melitus akan berisiko katarak sebesar 4,750 kali dibandingkan dengan responden yang tidak menderita diabetes melitus. Hal ini terjadi karena adanya peningkatan enzim aldose reduktase, sehingga lama-kelamaan peningkatan enzim ini dapat menyebabkan kekeruhan terhadap lensa dan menimbulkan katarak (Pollreisz and Schmidt-Erfurth, 2010; Fauzi and Hadisaputro, 2014).

Penelitian ini sejalan dengan hasil penelitian Arimbi (2012) dan Li Li et al (2014) yang menyatakan bahwa pasien yang menderita penyakit diabetes melitus meningkatkan risiko katarak dibandingkan yang tidak menderita diabetes melitus (Arimbi, 2012; Li et al., 2014). Hasil yang sesuai juga diperoleh dari penelitian yang dilakukan

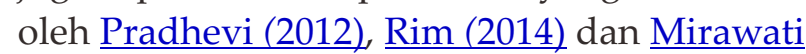
(2016) juga menunjukkan bahwa diabetes melitus signifikan secara statistik dengan kejadian katarak (Pradhevi et al., 2012; Rim et al., 2014; Wati, 2016). Maka, sangat penting bagi penderita diabetes melitus untuk mengontrol kadar gula darah sacara rutin sehingga mencegah terjadinya katarak.

Penyakit hipertensi merupakan suatu kondisi tubuh dimana terjadi peningkatan tekanan darah seseorang $\geq 140 \mathrm{mmHg}$ (tekanan darah sistolik) dan atau $\geq 90 \mathrm{mmHg}$ (tekanan darah diastolik)(WHO, 2012). Hasil penelitian diperoleh bahwa responden yang menderita hipertensi akan berisiko katarak sebesar 4,955 kali dibandingkan dengan responden yang tidak menderita hipertensi. Penelitian yang dilakukan oleh The Framingham Eye Study menemukan hubungan tekanan darah sistolik yang tinggi dengan kejadian katarak. Disamping itu, Barbados Eye Study menyatakan bahwa tekanan darah diastolik juga berhubungan dengan meningkatnya risiko kekeruhan lensa (Hasmeinah et al., 2012).
Penelitian ini menunjukkan bahwa sebagian besar pasien katarak memiliki tekanan darah yang tinggi sebelum menderita katarak.

Hasil penelitian ini sejalan dengan penelitian Yu et al (2014) dan Mehta et al (2016) menemukan bahwa risiko katarak lebih tinggi pada pasien hipertensi dibandingkan dengan pasien non hipertensi (Yu et al., 2014; Mehta et al., 2016). Demikian pula halnya dengan penelitian yang dilakukan oleh Rim et al (2014) yang menyatakan bahwa hipertensi memiliki hubungan yang signifikan secara statistik terhadap kejadian katarak (Rim et al., 2014). Oleh karena itu, penting bagi penderita hipertensi agar melakukan pencegahan dengan kontrol tekanan darah dan menghindari faktor risikonya sehingga komplikasi katarak dapat dihindari.

Merokok merupakan salah satu kebiasaan yang akan memberikan banyak dampak negatif terhadap kesehatan. Asap rokok yang mengandung radikal bebas dapat menyebabkan perubahan molekul protein sehingga dapat menimbulkan kekeruhan lensa. Pada penelitian ini diperoleh hasil bahwa responden yang memiliki kebiasaan merokok berisiko 3,696 kali lebih besar untuk menderita katarak dibandingkan dengan yang tidak memiliki kebiasaan merokok.

Hasil penelitian ini sejalan dengan penelitian yang dilakukan oleh Pujiyanto (2004) dan Wu (2010) bahwa orang yang memiliki kebiasaan merokok berisiko untuk terkena katarak dibandingkan dengan yang tidak memiliki kebiasaan merokok (Pujiyanto, 2004; Wu et al., 2010). Ini juga sesuai dengan hasil studi Lu et al (2012) dan Lindblad et al (2014) juga menyebutkan bahwa terdapat risiko katarak pada responden yang pernah merokok atau masih merokok dibandingkan dengan yang tidak pernah merokok (Lu et al., 2012; Lindblad et al., 2014). Berhenti merokok dan tidak merokok merupakan salah satu cara untuk mencegah risiko terjadinya katarak. 


\section{KESIMPULAN DAN SARAN}

Faktor yang secara signifikan berisiko terhadap kejadian katarak yaitu diabetes melitus, hipertensi, dan kebiasaan merokok. Olehnya, sangat penting untuk rutin mengontrol gula darah, tekanan darah, dan berhenti merokok. Juga diperlukan penelitian lebih lanjut terkait faktor risiko katarak dengan menambahkan variabel yang diteliti dalam penelitian ini.

\section{DAFTAR PUSTAKA}

Arimbi, A. T. (2012). Faktor-Faktor yang Berhubungan dengan Katarak Degeneratif di RSUD Budhi Asih Tahun 2011. Universitas Indonesia.

Badan Penelitian dan Pengembangan Kesehatan. (2008). Riset Kesehatan Dasar (Riskesdas) 2007. Jakarta: BPPK

Badan Penelitian dan Pengembangan Kesehatan. (2013). Riset Kesehatan Dasar. Jakarta: BPPK.

BKMM Makassar. (2016). Data Sekunder Penyakit Mata Balai Kesehatan Mata Masyarakat Makassar.

Fauzi, A. and Hadisaputro, S. (2014). Risk Factors of Cataract in Type 2 Diabetes Melitus. JUKE Universitas Lampung, $4(8)$.

Hasmeinah, H., Ansori, I. Z. and Meidawaty, D. S. (2012). Hubungan Angka Kejadian Katarak Senilis dengan Hipertensi di Poliklinik Rawat Jalan RSMP Periode JanuariDesember 2010. Syifa' Medika: Jurnal Kedokteran dan Kesehatan, 2(2). doi: https://doi.org/10.32502/sm.v2i2.1437 .g1220.

Ilyas, S. (2009). Ikhtisar Ilmu Penyakit Mata. Jakarta: Balai Penerbit.

Ilyas, S. (2014). Ilmu Penyakit Mata. Edited by S. R. Yulianti. Jakarta: Badan Penerbit Fakultas kedokteran Universitas Indonesia.
Lemeshow, S. (1997). Besar Sampel dalam Penelitian Kesehatan. Yogyakarta: Gadjah Mada University Press.

Li, L., Wan, X. and Zhao, G. (2014). Metaanalysis of the risk of cataract in type 2 diabetes. BMC Ophthalmology, 14(1), p. 94. doi: https://doi.org/10.1186/14712415-14-94.

Lindblad, B. E., Håkansson, N. and Wolk, A. (2014). Smoking Cessation and the $\mathrm{R}$ is k of Cataract. J $A M A$ Ophthalmology, 132(3), p. 253. doi: https://doi.org/10.1001/jamaophthal mol.2013.6669.

Lu, Z.-Q. et al. (2012). Cigarette smoking, body mass index associated with the risks of age-related cataract in male patients in northeast China. International journal of ophthalmology, 5 ( 3 ), p p. 317-22. d o i : https://doi.org/10.3980/j.issn.22223959.2012.03.13.

Mehta, R., Patil, M. and Page, S. (2016). Comparative study of cataract in hypertensive patients and nonhypertensive patients. Indian Journal of Clinical and Experimental Ophtalmology, 2(2), pp.153-157.

Pollreisz, A. and Schmidt-Erfurth, U. $\left(\begin{array}{llll}2 & 0 & 1 & 0\end{array}\right) . \quad$ D i a b e t i c Cataract - Pathogenesis, Epidemiology and Treatment. Journal of Ophthalmology, 2010, pp. 1-8. doi: https://doi.org/10.1155/2010/608751.

Pradhevi, L., Moegiono and Atika. (2012). Effect of Type-2 Diabetes Mellitus on Cataract Incidence Rate at Ophthalmology Outpatient Clinic, DR. Soetomo Hospital, Surabaya. Polia Medica Indonesia, 48(3), pp. 137-143.

Pujiyanto, T. I. (2004). Faktor-Faktor Risiko yang Berpengaruh Terhadap Kejadian 
Katarak Senilis (Studi Kasus di Kota Semarang dan Sekitarnya). Universitas Diponegoro.

Pusdatin Kementerian Kesehatan RI (2014) Infodatin: Situasi Gangguan Penglihatan dan Kebutaan. Jakarta Selatan.

Ravindran et al. (2013). Risk Factors Associated with the Development of Cataract : A Prospective Study. World Journal of Pharmacy and Pharmaceutical Sciences. 3(1):544-553.

Rim, T. H. T. et al. (2014). Cataract subtype risk factors identified from the Korea National Health and Nutrition Examination survey 2008-2010. BMC Ophthalmology, 14(1), p. 4. doi: https://doi.org/10.1186/1471-2415-14$\underline{4}$.

Varma, R. et al. (2016). Prevalence of Lens Opacities in Adult Chinese Americans: The Chinese American Eye Study (CHES). Investigative ophthalmology \& visual science, 57(15), p p. $6692-6699$. d o i : https://doi.org/10.1167/iovs.16-20517. Wati, M. (2016). Faktor-faktor yang berhubungan dengan kejadian katarak di Poli Mata RSUD DR. M. Yunus Bengkulu Tahun 2015. Journal of Nursing and Public Health, 4(1).

Weintraub, J. M. et al. (2002). Smoking cessation and risk of cataract extraction among US women and men. American journal of epidemiology, 155 ( 1 ), p p. $72-9$. d o i : https://doi.org/10.1093/aje/155.1.72.

WHO (2012) Global Data on Visual Impaiments 2010. Geneva, Switzerland.

Wu, R. et al. (2010). Smoking, socioeconomic factors, and agerelated cataract: The Singapore Malay Eye study. Archives of ophthalmology (Chicago, Ill. : 1960), 128(8), pp. $1029-35$. d o i : https://doi.org/10.1001/archophthalm ol.2010.147.

Yu, X. et al. (2014). Hypertension and Risk of Cataract: A Meta-Analysis', PLoS ONE. Edited by V. Jhanji, 9(12), p. e114012.doi:https://doi.org/10.1371/jo urnal.pone.0114012. 